\title{
ITS-rDNA phylogeny of Colletotrichum spp. causal agent of apple glomerella leaf spot
}

\author{
Filogenia por ITS-rDNA de Colletotrichum spp., agente causal da mancha foliar da Gala em macieira
}

\author{
Diorvania Ribeiro Giaretta ${ }^{\mathrm{I}}$ Amauri Bogo ${ }^{\mathrm{I} *}$ Cileide Maria Medeiros Coelho ${ }^{\mathrm{I}}$ \\ Altamir Frederico Guidolin' Adriana Cibele de Mesquita Dantas ${ }^{\text {II }}$ Eliane Aparecida Gomes ${ }^{\text {III }}$
}

\begin{abstract}
Several diseases have affected apple production, among them there is Glomerella leaf spot (GLS) caused by Colletotrichum spp. The first report of this disease in apple was in plants nearby citrus orchards in São Paulo State, Brazil. The origin of this disease is still not clear, and studies based on the molecular phylogeny could relate the organisms evolutionarily and characterize possible mechanisms of divergent evolution. The amplification of 5.8S-ITS (Internal Transcribed Spacer) of rDNA of 51 pathogenic Colletotrichum spp. isolates from apples, pineapple guava and citrus produced one fragment of approximately 600 bases pairs (bp) for all the isolates analyzed. The amplified fragments were cleaved with restriction enzymes, and fragments from 90 to 500bp were obtained. The sequencing of this region allowed the generation of a phylogenetic tree, regardless of their hosts, and 5 isolated groups were obtained. From the in silico comparison, it was possible to verify a variation from 93 to $100 \%$ of similarity between the sequences studied and the Genbank data base. The causal agent of GLS is nearly related (clustered) to isolates of pineapple guava and to the citrus isolates used as control.
\end{abstract}

Key words: pineapple guava, citrus, molecular phylogeny, in silico, phylogenetic tree.

\section{RESUMO}

A produção de maçã vem sendo comprometida pela ocorrência de muitas doenças, entre as quais se destaca a Mancha Foliar de Glomerella (MFG), causada por Colletotrichum spp. O primeiro relato dessa doença em maçã foi registrado em plantas próximas a pomares de citrus no Estado de São Paulo, Brasil. A origem da MFG ainda não está bem clara, e estudos baseados na filogenia permitirão relacionar o organismo evolutivamente, possibilitando

\begin{abstract}
caracterizar possíveis mecanismos divergentes de evolução. A amplificação da região 5.8S-ITS (espaçador interno transcrito) do rDNA de 51 isolados de Colletotrichum patogênicos em de maçã, goiabeira serrana e citrus produziu um fragmento de aproximadamente 600 pares de bases ( $p b$ ) para todos os isolados analisados. Os fragmentos amplificados foram digeridos por enzimas de restrição, sendo obtidos fragmentos de 90 a 500pb. O sequenciamento dessa região permitiu a construção de uma árvore filogenética com a distribuição dos isolados em cinco grupos, independentemente de seus hospedeiros. A partir da comparação in silico, foi possível verificar uma variação de 93 a 100\% de similaridade entre as sequências estudadas e o banco de dados do GenBank. O agente causal da MFG está relacionado (agrupado) a isolados de goiabeira serrana e aos isolados padrões de citrus.
\end{abstract}

Palavras-chave: goiabeira serrana, citrus, filogenia molecular, in silico, árvore filogenética.

\section{INTRODUCTION}

The apple (Malus domestica Borkh) is one of the most important fruits on the Brazil production, which reached almost -1 million tons in the 2007/2008 harvest (FINEP, 2009). Many factors restrict the crop expansion, among them, the incidence of disease like Glomerella leaf spot (GLS). This is one of the most important diseases of apple in southern Brazil (KATSURAYAMA et al., 2000; ARAÚJO et al., 2008) resulting in up to $70 \%$ of leaf defoliation in the cultivar Gala (CAMILO \& DENARDI, 2002). The most common

ILaboratório de Análises Genéticas, Departamento de Agronomia, Centro de Ciências Agroveterinário (CAV), Universidade do Estado de Santa Catarina (UDESC). Av. Luis de Camões, 2090, 88500-000, Lages, SC, Brasil. E-mail: a2ab@cav.udesc.br.*Autor para correspondência.

IIUniversidade Federal de Santa Catarina (UFSC), Florianópolis, SC, Brasil.

IIIEmbrapa Milho e Sorgo (CNPMS), Sete Lagoas, MG, Brasil. 
causal agent of GLS is Colletotrichum gloeosporioides (Penz.) Penz. \& Sacc. Others Colletotrichum spp related to GLS is C. acutatum (Schwein.) Andrus \& W. D. (SUTTON \& SANHUEZA, 1998), but there is a large genetic variability among these isolates.

This pathogen can also cause damages in several other crops, such as citrus, guava, mango, strawberry, bean and tomato (FREEMAN et al., 2001) and its origin and dissemination are not clear yet. Therefore some species of Colletotrichum, due to high genetic variability, can establish parasitic relations with some hosts (FREEMAN et al., 2001). This disease can be detected concomitantly in some pineapple guava (Acca sellowiana L.) and citrus (Citrus sinensis L.) orchards in hot regions. Apple orchards in south Brazil usually are near by native subtropical forest and the genus Colletotrichum has also caused problems in pineapple guava and others native species.

When genetic variability was evaluated based on the sequence variation in the ITS1 and ITS2 regions, without morphological influence, $\boldsymbol{C}$. acutatum isolates were highly similar (99-100\% nucleotide identity) while C. gloeosporioides isolates diverged into separates groups that were not associated with morphotype. However, with the possibility of strains arising in the pathogen population, studies that allow clarifying the origins of GLS are necessary (CHEN et al., 2006).

DNA molecular markers have assisted in estimating the genetic diversity between different isolates and degrees of relationship (HAMADA, 2005). The study of rDNA (ribosomal DNA) allows phylogenetic studies of the species, enables the differentiation of isolates inside of each species. The construction of a phylogenetic tree indicates the evolutionary history of an organism, supposing relations of ancestry for a set of species (CROUCH et al., 2009).

There is a large archive of Colletotrichum and Glomerella ITS sequences already deposited in the International Nucletoide Sequence Databases and these data are being used frequently for species diagnosis in the genus (MORIWAKY et al., 2002; LOBUGLIO \& PFISTER, 2008; CROUCH at al., 2009). With the recent movement within the mycological community to build a universal ITS-based barcoding platform, addressing the reliability of the Colletotrichum ITS sequence is critically important.

To consider this question, the objective of this research was to investigate the phylogenetic relation among isolates of the genus Colletotrichum, causal agent of GLS in apple and pineapple in southern Brazil, by ITS sequence analysis and comparison of these sequence to others described sequence in the literature.

\section{MATERIAL AND METHODS}

From a group of 87 Colletotrichum spp. monosporic isolates from symptomatic leaves of apple, pineapple guava and citrus from different part of Brazil, 39 from EPAGRI Institute (São Joaquim, Brazil) apple's collection, 10 from pineapple guava and 2 from Fundecitrus Institute (São Paulo, Brazil) citrus' collection were selected to investigate the phylogenetics relations by amplification and sequence analysis of ITS1-5.8S-ITS2 (Internal Transcribed Spacer). Only 10 out of 45 pineapple guava isolates and 2 out of 20 citrus isolates were selected based on different BDA media characteristics like colony color, conidial shape and ability to produce perithecia. The isolates were grown in $200 \mathrm{~mL}$ of liquid medium $(24 \mathrm{~g}$ liter ${ }^{-1}$ of potato sucrose broth - PSB Difco Laboratories). Cultures were shaken at $100 \mathrm{rpm}$ for 7 days at $24^{\circ} \mathrm{C}$. Mycelium was harvested by filtration through mesh sieves $(40 \mu \mathrm{m})$, washed with sterile water, deposited onto Whatman paper to remove excess water and liofilizated for $24 \mathrm{hs}$ at $-20^{\circ} \mathrm{C}$. The DNA extraction was made with $0.5 \mathrm{~g}$ of freeze-dried mycelium followed by SCHÄFER \& WÖSTEMEYER (1992) methodology and modified by JUNGHANS et al. (1998). DNA concentration was estimated by comparison with the DNA standards using $0.8 \%$ agarose gel electrophoresis with TBE buffer $(0.89 \mathrm{M}$ tris-borate and $0.02 \mathrm{M}$ EDTA), and stained with ethidium bromide $\left(0.5 \mu \mathrm{g} \mathrm{mL}^{-1}\right)$. The DNA extracted was cleaned with phenol, chloroform and isoamylic alcohol $(25: 24: 1)$ and $5 \mathrm{M}$ of $\mathrm{NaCl}$. The images were captured and stored under UV light using a photodocumentation system (Eagle Eye II, Stratagene).

The 5.8S-ITS region of rDNA isolates
was amplified by primers ITS 1

(5'TCCGTAGGTGAACCTGCGG3') and ITS4 (5'TCCTCCGCTTATTGATATGC3') (WHITE et al., 1990). The amplifications were performed in Thermocycler Hybaid PCR Express (Hybaid, UK) programmed to carry out an initial denaturation of 4 minutes at $94^{\circ} \mathrm{C}$, followed by 30 cycles; each cycle consists of denaturation $\left(30\right.$ seconds at $\left.94^{\circ} \mathrm{C}\right)$, annealing $\left(60\right.$ seconds at $\left.55^{\circ} \mathrm{C}\right)$, extension $(90$ seconds at $72^{\circ} \mathrm{C}$ ) and a final extension at $72^{\circ} \mathrm{C}$ for 10 minutes. PCR reactions $(50 \mu \mathrm{L})$ consisted of $60 \mathrm{ng}$ of DNA template, $1 \mu \mathrm{M}$ of each primer, buffer $1 \mathrm{X}(10 \mathrm{mM}$ Tris$\mathrm{HClpH} 8.3,50 \mathrm{mMKCl}), 3 \mathrm{mM}$ of $\mathrm{MgCl}_{2}, 100 \mu \mathrm{M}$ of each dNTP, $1.25 \mathrm{U}$ of Taq DNA polymerase. After the amplification, the PCR products were evaluated in agarose gel $2 \%$ in buffer TBE $1 X$.

The PCR products were digested with restricted endonucleases Rsa I, Alu I, Hinf I, Hpa II, 
Hha I, Xho I, Acc I, Eco RI e Taq I (Invitrogen do Brasil, São Paulo-SP), following the recommendations of the manufacturer for each enzyme. The profile revelation of restriction was made in agarose gel $2 \%$, analyzing the grouping of the haplotypes samples.

The amplification products corresponding to ITS region of rDNA of all Colletotrichum spp. isolates were purified by using the kit QIAquick Gel Extraction Kit 250 (Qiagen, Hilden, Germany). The sequencing reactions of 5.8S-ITS region were carried through with kit ABI PRISM Big Dye Terminator Cycle Sequencing Ready Reaction v.3.1 (Applied Biosystems, Foster City, California, the USA) and processed in the automatic DNA ABI PRISM 3100 Genetic Analyser (Applied Biosystems - Hitachi). After ITS region sequence, in silico comparison was done in which, the sequences obtained were edited by software SeqScape 2.5 of the Applied Biosystems and were used to search for similar sequences by using Blast $\mathrm{N}$ software (ALTSCHUL et al., 1990) of the NCBI (http:// www.ncbi.nlm.nih.gov). The edited sequences were then lined up in ClustalW software and a NeighborJoining phylogenetic tree was constructed from Kimura 2-parameter pairwise distances using the Molecular Evolutionary Genetics Analysis software MEGA 3.1 (SAITON \& NEI, 1987). The consistency of phylogenetic resolution was supported by bootstrap analysis using 1.000 replicates. The DNA sequences obtained from Colletotrichum isolates and from GenBank were used for phylogenetic analysis with a preliminary species identification performance based on the best matches from GenBank accessions in order to estimate the ability of the ITS sequence to accurately pinpoint species identity using database matches, evalues, similarity scores and through the distance tree of search results constructed by the GenBank interface (minimum evolution option).
New sequence data of Colletotrichum isolates were deposited in the GenBank Nucleotide (accession numbers EU008828 to EU008878).

\section{RESULTS AND DISCUSSION}

The PCR products obtained by amplification of ITS1-5.8S-ITS2 region of the ribosomal DNA of all Colletotrichum spp. isolates presented approximately 600 bases pairs (bp), corroborating with the data obtained by FREEMAN et al. (2001) and CULEBRAS et al. (2003), which obtained the same fragments size.

A variation of fragments from 90 to $500 \mathrm{bp}$ was obtained after digestion with the restriction endonucleases Rsa I, Alu I, Hinf I, Hpa II, Hha I, Xho I, Acc I, Eco RI and Taq I (Tables 1 and 2). These fragments were relatively short and appeared in high numbers of copies in the genome and were easily amplified because it had highly conservative regions and joined by spacers (ITS) that can be highly polymorphic and provide useful tools for taxonomic and phylogenetic studies (CHEN et al, 2006). From the restriction fragments of the amplified ITS- rDNA region of the 51 isolates were obtained 1 to 3 restriction enzyme fragments, which two profiles for Acc I enzyme, 3 for Hpa II, 4 for Eco RI, Hinf I, Rsa I, Alu I, Taq I and Hha I (Table 1 and 2).

The results of the confrontation between DNA analysis of the isolates and the GenBank data base through Blast (Table 3) ranged from 99 to $100 \%$ of similarity, supposing good trustworthiness. This high percentage of similarity identified genetically the isolates, which allowed relating the sequences of the ones of the GenBank (CROUCH et al. (2009); LOBUGLIO \& PFISTER (2008) and MORIWAKI et al. (2002). The use of the sequences of the ITS region of the

Table 1 - Restriction fragments (bases of pairs-bp) of the endonucleases used in rDNA internal transcribed spacer (ITS) amplified of Colletotrichum spp. isolates from apple (M) and pineapple guava (G), produced by the restriction enzymes Rsa I, Alu I, Hha I, Eco RI . Two isolates from citrus (C1 and $\mathrm{C} 2$ ) were used as comparison control. NC - did not cleave.

\begin{tabular}{|c|c|c|c|c|}
\hline Isolates & Rsa I & Alu I & Hha I & Eco RI \\
\hline M1and M2 & $\mathrm{NC}$ & $\mathrm{NC}$ & $270,185,125$ & 320,290 \\
\hline M3 to M6 & 390,190 & 365,175 & $270,185,145$ & 290,330 \\
\hline M7 & $\mathrm{NC}$ & 385,200 & $270,185,155$ & 320,300 \\
\hline M8 to M30 & 390,190 & 365,175 & $270,185,145$ & 290,330 \\
\hline M31 to M37 & $\mathrm{NC}$ & $\mathrm{NC}$ & $270,185,125$ & 320,290 \\
\hline M38 to M40 & $\mathrm{NC}$ & $\mathrm{NC}$ & $270,185,145$ & 320,290 \\
\hline G1 to G10 & 380,180 & 365,175 & $270,185,145$ & 290,300 \\
\hline $\mathrm{C} 1$ & 380,180 & 360,195 & $270,185,145$ & 290,330 \\
\hline $\mathrm{C} 2$ & 500 & $\mathrm{NC}$ & $185,280,135$ & 315,295 \\
\hline
\end{tabular}


Table 2 - Restriction fragments (bases of pairs-bp) of the endonucleases used in rDNA internal transcribed spacer (ITS) amplified of Colletotrichum spp. isolates from apple (M) and pineapple guava $(\mathrm{G})$, produced by the restriction enzymes Hinf I, Acc I, Taq I, Hpa II (NC - did not cleave). C1 and C2 citrus isolates were used as comparison control.

\begin{tabular}{lllll}
\hline & & \multicolumn{2}{c}{ Size of restriction fragment (bp) } \\
\hline isolates & Hinf I & Acc I & Taq I & Hpa II \\
M1 à M2 & $300,185,90$ & NC & 250,250 & $280,145,125$ \\
M3 à M6 & $90,295,190$ & NC & 250,125 & $125,280,120$ \\
M7 & $90,315,190$ & 400,160 & 255,135 & $120,290,130$ \\
M8 à M30 & $90,295,190$ & NC & 250,240 & $125,280,120$ \\
M31 à M37 & $300,185,90$ & NC & 250,250 & $120,145,125$ \\
M38 à M40 & $90,295,190$ & NC & 240,245 & 130 \\
G1 à G10 & $90,295,190$ & NC & 250,240 & $125,280,120$ \\
C1 & $300,90,190$ & NC & 250,240 & \\
C2 & $90,295,190$ & NC & 240,245 & $120,290,130$ \\
\hline
\end{tabular}

Colletotrichum isolates, enabled to visualize all isolates by species, independent of the host (Figure 1). The same procedure has been done by FUNGARO (2000), which separated isolates in distinct species by rDNA analysis and consequently the differentiation of the isolates inside of each species. CROUCH et al. (2009) tested the utility of ITS sequence data to diagnose species affiliations through similarity-based searches of the NCBI GenBank database or by means of gene trees constructed using phylogenetic methods.

The sequence of ITS1-5.8S-ITS2 region of the M7 isolate, presented lowest values of similarity among the sequences, varying from 93 to $100 \%$, while for the others isolates, the values were between 97 to $100 \%$ (Figure 1). The bootstrap analysis presented values in an average of $70 \%$, indicating a good reliability in the obtained results, according to CROUCH et al. (2009); LOBUGLIO \& PFISTER (2008) and MORIWAKI et al. (2002). The differences in values of similarity amongst M7 and all others isolates can be related to the pathogenic effect. All isolates were pathogenic (data not presented) causing symptoms in apple leaves and fruits, except the M7 isolate which did not cause either symptoms in apple leaves or in wounded fruits, justifying lower values. These data corroborates with HAMADA (2005), which mentioned that the M7 isolate, only produced mycelium on the inoculated tissues, which was saprophytic. The fact of M7 isolate was not pathogenic and mentionedl by HAMADA (2005) justified the fact that M7 isolate did not grouped with the other isolates of the same species. The phylogenetic tree produced 5 groups and the Group I of C. gloeosporioides isolates from apple appears in the same ramification of the Group II, which is also founded in the branch of the Group III of pineapple guava isolates (Figure 1).

To increase the evidences that the Colletotrichum spp., causal agent of GLS, has a close relation with Colletotrichum spp. of pineapple guava, an in silico comparison was made with the sequences of the GenBank database with the sequences of all Colletotrichum isolates evaluated (Table 3). From the in silico comparison, was possible to verify a variation from 93 to $100 \%$ of similarity between the sequences studied with the Genbank data base. This confirmed the genus and species of the fungi studied and reinforced that the causal agent of the GLS is phylogenetically related to the fungi which causes some diseases in tropical or subtropical crops, and even in pineapple guava since some species of this fungi, such as $\boldsymbol{C}$. gloeosporioides and $\boldsymbol{C}$. acutatum, can establish parasitic relations with several hosts.

The DNA sequencing showed differences and similarities between Colletotrichum isolates, which allowed relating all isolates according to the degree of relationship. The ITS region of rDNA of the apple Colletotrichum spp. isolates is phylogenetically related with the ITS region of rDNA of Colletotrichum spp. from pineapple guava with similarity higher than $93 \%$. This value can be considered low when different species were classified inside the species by formae speciales (SREENIVADAPRADAD al., 1996) but high when involve different species in this case.

These results corroborant with previous studies on the diversity of this pathogen in Brazilian conditions (KATSURAYAMA et al., 2000; VALÉRIO 
Table 3 - Confrontation analysis of the sequences obtained through Blast ${ }_{n}$ of the GenBank data base with the closest species by highest score, E-value and similarity.

\begin{tabular}{|c|c|c|c|c|c|}
\hline Access & Blast $_{n}$ & species & score & E-value & similarity \\
\hline M1 & AM404289.1 & C. acutatum & 922 & 0.0 & $100 \%$ \\
\hline M2 & AB219041.1 & C. acutatum & 1007 & 0.0 & $100 \%$ \\
\hline M3 & AB219012.1 & C. gloeosporioides & 1082 & 0.0 & $100 \%$ \\
\hline M4 & AB219012.1 & C. gloeosporioides & 1084 & 0.0 & $100 \%$ \\
\hline M5 & AB219012.1 & C. gloeosporioides & 1112 & 0.0 & $100 \%$ \\
\hline M6,11,21 & AB255249.1 & C. gloeosporioides & 1106 & 0.0 & $99 \%$ \\
\hline M7 & DQ780420.1 & C. gloeosporioides & 833 & 0.0 & $100 \%$ \\
\hline M8 & AB219012.1 & C. gloeosporioides & 1007 & 0.0 & $100 \%$ \\
\hline M9 & DQ780452.1 & C. gloeosporioides & 1021 & 0.0 & $99 \%$ \\
\hline M10 & AB219012.1 & C. gloeosporioides & 1124 & 0.0 & $100 \%$ \\
\hline M12 & DQ780452.1 & C. gloeosporioides & 942 & 0.0 & $100 \%$ \\
\hline M13 & AB255249.1 & C. gloeosporioides & 1008 & 0.0 & $99 \%$ \\
\hline M14 & DQ780452.1 & C. gloeosporioides & 942 & 0.0 & $100 \%$ \\
\hline M15,22,26 & AB219012.1 & C. gloeosporioides & 1090 & 0.0 & $100 \%$ \\
\hline M16 & AB219012.1 & C. gloeosporioides & 993 & 0.0 & $100 \%$ \\
\hline M17 & AJ301986.1 & C. gloeosporioides & 1088 & 0.0 & $99 \%$ \\
\hline M18,20,24,25 & AB219012.1 & C. gloeosporioides & 1088 & 0.0 & $100 \%$ \\
\hline M19 & AB255249.1 & C. gloeosporioides & 1098 & 0.0 & $99 \%$ \\
\hline M27,28,29 & AB219012.1 & C. gloeosporioides & 1092 & 0.0 & $100 \%$ \\
\hline M30 & AB219012.1 & C. gloeosporioides & 1088 & 0.0 & $100 \%$ \\
\hline M31 & AB219041.1 & C. acutatum & 1120 & 0.0 & $99 \%$ \\
\hline M32 & AB219041.1 & C. acutatum & 1108 & 0.0 & $100 \%$ \\
\hline M33 & AB219041.1 & C. acutatum & 1112 & 0.0 & $99 \%$ \\
\hline M34 & AB219041.1 & C. acutatum & 1057 & 0.0 & $99 \%$ \\
\hline M35,36 & AB219041.1 & C. acutatum & 1108 & 0.0 & $100 \%$ \\
\hline M37 & AM404289.1 & C. acutatum & 1098 & 0.0 & $100 \%$ \\
\hline M38 & DQ286119.1 & C. acutatum & 1088 & 0.0 & $99 \%$ \\
\hline M39 & DQ286119.1 & C. acutatum & 1090 & 0.0 & $99 \%$ \\
\hline M40 & AB219041.1 & C. acutatum & 1106 & 0.0 & $99 \%$ \\
\hline G1 & AJ301912.1 & Colletotrichum sp. & 1047 & 0.0 & $99 \%$ \\
\hline G2 & DQ003092.1 & Colletotrichum sp. & 1053 & 0.0 & $100 \%$ \\
\hline G3 & DQ003092.1 & Colletotrichum sp. & 1055 & 0.0 & $100 \%$ \\
\hline G4 & DQ780417.1 & Colletotrichum sp. & 878 & 0.0 & $99 \%$ \\
\hline G5 & AJ301912.1 & Colletotrichum sp. & 981 & 0.0 & $99 \%$ \\
\hline G6 & AJ301912.1 & Colletotrichum sp. & 1057 & 0.0 & $99 \%$ \\
\hline G7 & DQ003092.1 & Colletotrichum sp. & 942 & 0.0 & $100 \%$ \\
\hline G8 & DQ003092.1 & Colletotrichum sp. & 1049 & 0.0 & $100 \%$ \\
\hline G9 & AJ301912.1 & Colletotrichum sp. & 1063 & 0.0 & $99 \%$ \\
\hline G10 & DQ003092.1 & Colletotrichum sp. & 1015 & 0.0 & $100 \%$ \\
\hline $\mathrm{C} 1$ & AJ301988.1 & C. gloeosporioides & 1086 & 0.0 & $100 \%$ \\
\hline $\mathrm{C} 2$ & DQ286119.1 & C. acutatum & 1080 & 0.0 & $99 \%$ \\
\hline
\end{tabular}

et al., 2005) and the number of pineapple and citrus isolates used in this research may be considered low, but they were collected from different geographical regions and were morphologically different from the original group of apple's isolates, giving some direction of the same origin evidence, indicating that this disease has arrived in São Paulo and Paraná apple orchards from the subtropical or tropical crops like pineapple guava and citrus. However, a continuous monitoring of the population of this pathogen in the main areas of occurrence of the disease, and with larger samples, is needed. This will help the development of gene deployment strategies and, as consequence, better conditions for the development of the apple crop in Brazil.

Ciência Rural, v.40, n.4, abr, 2010. 


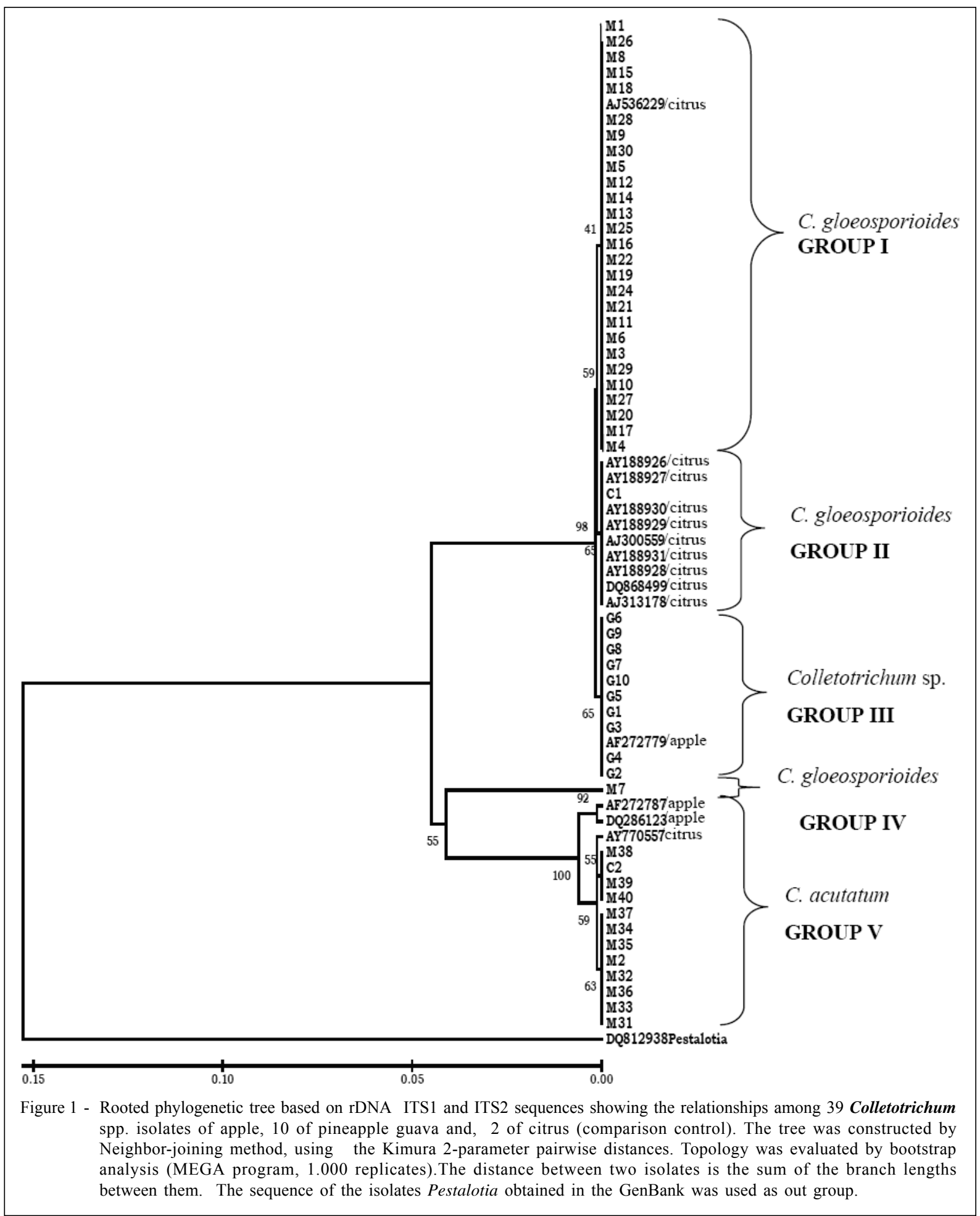

\section{REFERENCES}

ALTSCHUL, S.F. et al. Basic local alignment search tool. Journal of Molecular Biology, v.215, n.3, p.403-10, 1990.
ARAÚJO, L. et al. Fosfito de potássio e ulvana no controle da mancha foliar da gala em macieira. Tropical Plant Pathology, v.33, n.2, p.8-13, 2008. Available: <http://www.proterra.agr.br/ admin/imagens/pdf/07042009170208.pdf > . Acessed: 16 nov. 2009. doi: $10.1590 / \mathrm{S} 1982-56762008000200009$. 
CAMILO, A.P.; DENARDI, F. Cultivares: descrição e comportamento no Sul do Brasil. In: A cultura da macieira. Florianópolis: EPAGRI, 2002. p.113-168.

CHEN, L.S. et al. PCR-Based detection and differentiation of anthracnose pathogens, Colletotrichum gloeosporioides and $\boldsymbol{C}$. truncatum from vegeble soybean in Taiwan. Journal of Phytopathology, v.154, p.654-662, 2006. Available: <http:/ /www3.interscience.wiley.com/journal/118589085/ abstract?CRETRY=1\&SRETRY $=0>$. Accessed: 12 nov. 2009. doi: $10.1111 / \mathrm{j} .1439-0434.2006 .01163 . \mathrm{x}$

CROUCH, J.A. et al. What is the value of ITS sequence data in Colletotrichum systematics and species diagnosis? A case study using the falcate-spored graminicolous Colletotrichum group. Mycologia, v.101, p.648-656, 2009. Available: <http:// www.mycologia.org/cgi/content/abstract/08-231v1?ck=nck>. Accessed: 12 nov. 2009. doi: 10.3852/08-231.

CULEBRAS, P.V.M. et al. Phylogenetic relationships among Colletotrichum pathogens of strawberry and design of PCR primers for their identification. Journal of Phytopathology, v.151, p.135-143, 2003. Available: <http://www3.interscience.wiley.com/ journal $/ 118887794 /$ abstract? CRETRY $=1 \&$ SRETRY $=0>$. Accessed: 12 nov. 2009. doi:10.1046/j.1439-0434.2003.00694.

FINEP - Financiadora de Estudos e Projetos. Available: http:/ /www.finep.gov.br/imprensa/revista/edicao $5 /$ inovacao_em_pauta_5_pag43a47_macas.pdf. Accessed: 16 nov. $200 \overline{9}$.

FREEMAN, S. et al. Genetic diversity within Colletotrichum acutatum sensu Simmonds. Phytopathology, v.91, p.586592, 2001. Available: <http://apsjournals.apsnet.org/doi/abs/ 10.1094/PHYTO.2001.91.6.586>. Accessed: 12 nov. 2009. doi: 10.1094/PHYTO.2001.91.6.586.

FUNGARO, M.H.P. PCR na micologia. São Paulo: Ciência, 2000. 86p.

HAMADA, N.A. Caracterização morfológica, patogênica e molecular de isolados de Colletotrichum spp. em macieira. 2005. 92f. Dissertação (Mestrado em Recursos Genéticos Vegetais) - Universidade Federal de Santa Catariana, SC.

JUNGHANS, D.T. et al. Genetic diversity of the ectomycorrhizal fungus Pisolithus tinctorius based on RAPDPCR analysis. Mycorrhiza, v.7, p.243-248, 1998. Available: $<$ http://www.springerlink.com/content/gf079thj62x3qpr9/>. Accessed: 12 nov. 2009. doi: 10.1007/s005720050187.
KATSURAYAMA, Y. et al. Mancha foliar da gala: principal doença de verão da cultura da macieira. Agropecuária Catarinense, v.13, p.14-19, 2000.

LOBUGLIO, K.F.; PFISTER, D.H. A Glomerella species phylogenetically related to Colletotrichum acutatum on Norway maple in Massachussetts. Mycologia, v.100, p.710-715, 2008. Available: <http://www.mycologia.org/cgi/content/abstract/100/ 5/710>. Accessed: 16 nov. 2009. doi: 10.3852/07-192.

MORIWAKI, J. et al. Grouping of Colletotrichum species in Japan based on rDNA sequences. Journal of General Plant Pathology, v.68, p.307-320, 2002. Available: <http:// www.springerlink.com/content/nagt $7 \mathrm{~m} 684$ planv7f/>. Accessed: 12 nov. 2009. doi: 10.1007/PL00013096.

SAITON, N.; NEI, M. The neighbor-joining method: A new method for reconstructing phylogenetic trees. Molecular Biology and Evolution, v.4, p.406-425, 1987.

SCHÄFER, C.; WÖSTEMEYER, J. Random primer dependent PCR differentiates aggressive from non-aggressive isolates of the oilseed rape pathogen Phoma lingam (Leptosphaeria maculans). Journal of Phytopathology, v.136, p.24-136, 1992. Available: $<$ http://cat.inist.fr/?aModele $=$ afficheN\&cpsidt $=5500574>$. Accessed: 16 nov. 2009

SREENIVADAPRADAD, S. et al. Phylogeny and systematic of 18 Colletotrichum species based on ribosomal DNA spacer sequences. Genome, v.39, n.3, p.499-512, 1996. Available: $<$ http://rparticle.web-.cisti.nrc.ca/rparticle/ AbstractTemplateServlet?calyLang $=$ eng\&journa $1>$. Accessed: 12 nov. 2009. doi: $10.1139 / \mathrm{g} 96-064$.

SUTTON, T.B.; SANHUEZA, R.M.V. Necrotic leaf blotch of Golden Delicious-Glomerella leaf spot: a resolution of common names. Plant Disease, v.82, p.267-268, 1998. Available: $<$ http://apsjournals.apsnet.org/doi/abs/10.1094/ PDIS.1998.82.3.267>. Accessed: 12 nov. 2009. doi: 10.1094/ PDIS.1998.82.3.267.

VALÉRIO, H.M, et al. Virulence and molecular diversity in Colletotrichum graminicola from Brazil. Mycopathologia, v.159, p.449-459, 2005. Available: <http://www.springerlink.com/ content/xlk77n0r7788xpm1/>. Accessed: 25 feb. 2010 . doi: 10.1007/s11046-005-0373-y

WHITE, T.J et al. Amplification and direct sequencing of fungal ribosomal RNA genes for phylogenetics. In: INNIS, M.A. et al. (Eds). PCR protocols: a guide to methods and applications. San Diego: Academic, 1990. p.315-322. 